\title{
Atopic dermatitis in sickle cell children
}

\section{Shaima Ashwi ${ }^{1}$ *, Ahmad Alobaisy ${ }^{2}$, Nawal Herzallah ${ }^{3}$, Fatema Alwaheed ${ }^{4}$, Ibtihal Hadi ${ }^{1}$, Duaa Alabbas ${ }^{5}$, Faisal Al-Rasheed ${ }^{6}$, Nawaf Alshuraym ${ }^{7}$, Esra Alzein ${ }^{8}$}

College of Medicine, ${ }^{1}$ Jazan University, Jazan, ${ }^{6}$ Al-Jouf University, Al-Jouf, ${ }^{7}$ Imam Muhammad ibn Saud Islamic University, Riyadh, Saudi Arabia

Department of Pediatrics, ${ }^{2}$ King Salman Hospital, Riyadh, ${ }^{4}$ Dammam Medical Complex, Maternity and Children Hospital, Dammam, Saudi Arabia

${ }^{3}$ College of Medicine, Royal College of Surgeons in Ireland, Dublin, Ireland

${ }^{5}$ Primary Health Care, Al-Ahsa, Saudi Arabia

Received: 11 January 2018

Accepted: 29 January 2018

\section{*Correspondence:}

Dr. Shaima Ashwi,

E-mail: dr.shaimaashwi@hotmail.com

Copyright: () the author(s), publisher and licensee Medip Academy. This is an open-access article distributed under the terms of the Creative Commons Attribution Non-Commercial License, which permits unrestricted non-commercial use, distribution, and reproduction in any medium, provided the original work is properly cited.

\begin{abstract}
Sickle cell disease is an autosomal recessive disease characterized by recurrent vaso-occlusive events. Despite the genetic basis of its pathophysiology, recent researchers stated that it is an inflammatory immune-mediated disease where inflammation plays a crucial role in the initiation of adherence between sickle cells and vascular endothelial cells. Allergic, as well as infectious, inflammation is proposed to contribute to the initiation of vaso-occlusive events. Although several researchers reported an association between sickle cell disease and atopic conditions such as bronchial asthma and allergic rhino-conjunctivitis, few cases have reported an association between sickle cell disease and atopic dermatitis. Atopy was reported to be considerably linked to sickle cell disease for several reasons. Firstly, patients with sickle cell disease have higher IgE levels than the general population. Secondly, the mechanism of activation of molecular adhesion between endothelial and blood cells are similar between both sickle cell disease and atopic disease. Thirdly, the cytokines produced from platelet activation are the same cytokines that stimulate allergic inflammation in atopic diseases and promote adherence of sickle cells and endothelium in sickle cell disease. Lastly, sickle cell disease was reported to be associated with other atopic diseases.
\end{abstract}

Keywords: Atopic dermatitis, Sickle cell, Anemia, Atopy, Eczema, Pediatric, Children

\section{INTRODUCTION}

Sickle cell disease (SCD) is a genetic autosomal recessive disease that results from the existence of a mutated type of hemoglobin (hemoglobin S) and presents during early childhood with vaso-occlusive crises. Individuals who carry the sickle cell genes in homozygous forms present with sickle cell disease (SCD), whilst those who carry a single copy of the gene (heterozygous) are sickle cell carries. Clinically, patients with sickle cell disease present with manifestation of vascular occlusive phenomenon. ${ }^{1-3}$ Following hypoxia, dehydration, or change in body temperature, patients with sickle cell disease (SCD) experience vaso-occlusive manifestations including acute pains, bone pain, chronic hemolytic anemia, splenic sequestration or infarction, recurrent infection, growth retardation, dactylitis, dyspnea, acute chest syndrome, avascular necrosis of femur head, recurrent cerebrovascular stroke, recurrent thrombotic events, retinal hemorrhage, cardiac chamber dilatation, cholelithiasis, priapism, renal involvement, and lower extremity ulcers. ${ }^{4}$

Atopic dermatitis, on the other hand, is a chronic immune-mediated skin disease that is characterized with recurrent relapses of pruritis, xerosis, itching, hand or 
foot dermatitis, ichthyosis, cheilitis, palmar hyper linearity, or keratosis pilaris that start at early age of childhood in patients with family history of atopy such as atopic conjunctivitis, atopic rhinitis, or bronchial asthma. ${ }^{5}$ Atopic dermatitis is a cell-mediated immune disease characterized by increased levels of T-helper type 2 (Th2) cells as well as interleukin (IL) levels, particularly IL-3, IL-4, and IL-5. ${ }^{6}$ This review aims at addressing the potential association between atopic dermatitis and sickle cell disease.

\section{PATHOPHYSIOLOGY OF SICKLE CELL DISEASE}

The widely accepted pathophysiology of sickle cell disease is related to the altered physical properties of the mutated hemoglobin S. Under deoxygenated situations, hemoglobin $\mathrm{S}$ changes its physical characters, solubility, viscosity, stability, and morphology. It forms polymers and crystals in a gelatin-like substance that sickle repetitively leading to membrane damage, altered cell membrane permeability to $\mathrm{Na}^{+}, \mathrm{K}^{+}$, and $\mathrm{Ca}^{++}$, and subsequent alteration of cytoskeleton proteins. Additionally, the structure of the lipid bilayer of the cell membrane changes and the membrane becomes more rigid. This contributes to thrombosis and vaso-occlusive phenomena. Furthermore, the cells that carry hemoglobin $\mathrm{S}$ express on its surface very late antigen-4 (VLA-4) that interacts with molecules on the endothelial lining of blood vessels such as vascular cell adhesive molecule-1 (VCAM-1). Deformable cells adhere to vascular endothelium 10 times more than normal cells. Leucocytes, particularly neutrophils, also share by expressing adhesive molecules. $1,7,8$

\section{IMMUNOLOGY OF SICKLE CELL DISEASE}

Whilst the susceptibility of patients with sickle cell disease to recurrent infection has been long attributed to immunological alteration following splenic dysfunction, recent evidence suggests that sickle cell disease is an inflammatory disease with a persistent low-grade inflammation that is responsible for initiation of the vasoocclusive crisis. ${ }^{9-11}$ Researchers found that patients with sickle cell disease have high levels of acute phase reactants, serum amyloid $\mathrm{A}, \mathrm{C}$-reactive protein and orosomucoid during disease remissions and significantly higher levels during relapses. ${ }^{12}$ The inflammation encountered in patients with sickle cell disease activate vascular endothelium and enhance expression of adhesion molecules that interact with the deformed red blood cells leading to vascular occlusive events. ${ }^{10}$ Moore et al, in their review, suggested that the inflammatory reaction that promotes adhesion between sickle cells and vascular endothelium can be allergic or infectious inflammation. ${ }^{10}$ The postulation of the allergic inflammation theory was proposed based on the demonstration of similar mechanisms of activation of endothelium and expression of adhesion molecules after immunoglobulin $\mathrm{E}$ ( $\mathrm{IgE}$ ) activation in patients with bronchial asthma and atopic dermatitis. $^{13,14}$

\section{SICKLE CELL DISEASE AND ATOPY}

During the past few decades, evidence from literature studies supported the existence of an association between sickle cell disease and atopy. Firstly, significantly elevated levels of $\operatorname{IgE}$ were reported among patients with sickle cell disease in different researches, and the levels of $\mathrm{IgG}$ and $\operatorname{IgA}$ were also high. ${ }^{15,16}$ Secondly, the mechanism of activation of endothelium and increasing the expression and activity of adhesion molecules is encountered in other atopic diseases such as bronchial asthma and atopic dermatitis. ${ }^{13,14}$ Thirdly, the cytokine profile produced by activated $\mathrm{T}$ helper cells lead to allergic inflammation as well as upregulation of VCAM1 molecular expression on endothelial lining which will consequently recruit leucocytes to the site of inflammation. ${ }^{17}$ Lastly, the association between sickle cell disease and atopic diseases reported from the literature, as well as the increased severity, morbidity, and mortality with exacerbations of atopic diseases support the postulation that allergic inflammation plays a crucial role in the pathophysiology of sickle cell disease. ${ }^{10}$ For instance, several researches reported cases with sickle disease associated with bronchial asthma. ${ }^{16,18-}$

${ }^{20}$ They have reported that exacerbations of bronchial asthma were associated more severe symptoms of sickle cell disease and higher mortality rates, which support the theory of allergic inflammation nature of activation of endothelial molecular adhesion molecules and subsequent cascade of vaso-occlusive phenomena. Sickle cell disease in one study was found to be associated with asthma (aOR=1.46), bronchitis $(\mathrm{aOR}=1.71)$, and eczema $(\mathrm{aOR}=1.74)$. Cases of $\operatorname{IgA}$ nephropathy was also reported to be associated with sickle cell disease. ${ }^{21,22}$

\section{SICKLE CELL DISEASE AND ATOPIC DERMATITIS}

As aforementioned, sickle cell disease seems to be considerably associated with atopy and atopic diseases. Few studies from the literature have reported cases with sickle cell disease and atopic dermatitis. Data from the FDA reported five cases during the period 2010 to 2011 who had eczema and sickle cell disease. Females constituted the vast majority of those patients $(80 \%)$, whilst men constituted only $20 \%$. One of them had another co-existing atopic disease (bronchial asthma). ${ }^{23}$ Similarly, a cohort study conducted in Florida on children with sickle cell disease stated that - by multiple logistic Regression analysis- sickle cell disease was significantly associated to eczema $(\mathrm{aOR}=1.74,1.23-2.46) .{ }^{21}$

In atopic dermatitis, blood thrombospondin levels are elevated specifically with disease activity. ${ }^{24}$ These thrombospondins are thought to promote adherence between sickle cells and vascular endothelium through modulating antigens expressed on sickle cell surface such 
as VLA-4, CD36, and GPIIb/IIIa. Thrombospondins are produced by the activated platelets when an allergen binds to the platelet Fc-II- associated IgE. ${ }^{10}$

\section{CONCLUSION}

The genetic basis of sickle cell disease is not the only pathophysiologic mechanism encountered, growing evidence suggests that an inflammatory immunemediated pathology plays a crucial role as well. Inflammation is thought to promote adherence between sickle cells and vascular endothelial cells. Allergic, as well as infectious, inflammation is proposed to contribute to the initiation of vaso-occlusive events. Although several researchers reported an association between sickle cell disease and atopic conditions such as bronchial asthma and allergic rhino-conjunctivitis, few cases were found that reported an association between sickle cell disease and atopic dermatitis. Atopy was reported to be considerably linked to sickle cell disease for several reasons. Firstly, patients with sickle cell disease have higher IgE levels than the general population. Secondly, the mechanisms of activation of molecular adhesion between endothelial and blood cells are similar between both sickle cell disease and atopic disease. Thirdly, the cytokines produced from platelet activation are the same cytokines that stimulate allergic inflammation in atopic diseases and promote adherence of sickle cells and endothelium in sickle cell disease. Lastly, sickle cell disease was reported to be associated with other atopic diseases.

\section{Funding: No funding sources}

Conflict of interest: None declared

Ethical approval: Not required

\section{REFERENCES}

1. Rees DC, Williams TN, Gladwin MT. Sickle-cell disease. Lancet (London, England). 2010;376(9757):2018-31.

2. Serjeant GR. The Natural History of Sickle Cell Disease. Cold Spring Harbor Persp Med. 2013;3(10):a011783.

3. Piel FB, Steinberg MH, Rees DC. Sickle Cell Disease. New England J Med. 2017;376(16):156173.

4. Stuart MJ, Nagel RL. Sickle-cell disease. Lancet (London, England). 2004;364(9442):1343-60.

5. Bieber T. Atopic dermatitis. Annals Dermatol. 2010;22(2):125-37.

6. Turner JD, Schwartz RA. Atopic dermatitis. A clinical challenge. Acta dermatovenerologica Alpina, Pannonica, et Adriatica. 2006;15(2):59-68.

7. Manwani D, Frenette PS. Vaso-occlusion in sickle cell disease: pathophysiology and novel targeted therapies. Blood. 2013;122(24):3892-8.

8. Malowany JI, Butany J. Pathology of sickle cell disease. Seminars Diagnostic Pathol. 2012;29(1):4955 .
9. Pearson HA, Spencer RP, Cornelius EA. Functional asplenia in sickle-cell anemia. New England J Med. 1969;281(17):923-6.

10. Moore CM, Ehlayel M, Leiva LE, Sorensen RU. New concepts in the immunology of sickle cell disease. Annals of allergy, asthma \& immunology. American Coll Allergy, Asthma, Immunol. 1996;76(5):385-400.

11. Platt OS. Sickle cell anemia as an inflammatory disease. J Clin Investigation. 2000;106(3):337-8.

12. Krishnan S, Setty Y, Betal SG, Vijender V, Rao K, Dampier C, et al. Increased levels of the inflammatory biomarker $\mathrm{C}$-reactive protein at baseline are associated with childhood sickle cell vasocclusive crises. British J Haematol. 2010;148(5):797-804.

13. Hirai $\mathrm{S}$, Kageshita $\mathrm{T}$, Kimura $\mathrm{T}$, Tsujisaki $\mathrm{M}$, Okajima K, Imai K, et al. Soluble intercellular adhesion molecule-1 and soluble E-selectin levels in patients with atopic dermatitis. British J Dermatol. 1996;134(4):657-61.

14. Kobayashi T, Hashimoto S, Imai K, Amemiya E, Yamaguchi M, Yachi A, et al. Elevation of serum soluble intercellular adhesion molecule-1 (sICAM1) and sE-selectin levels in bronchial asthma. Clin Experimental Immunol. 1994;96(1):110-5.

15. An P, Barron-Casella EA, Strunk RC, Hamilton RG, Casella JF, DeBaun MR. Elevation of $\operatorname{IgE}$ in children with sickle cell disease is associated with doctor diagnosis of asthma and increased morbidity. Journal Allergy Clin Immunol. 2011;127(6):1440-6.

16. Mohapatra BN, Dash BP, Kar BC. Serum immunoglobulins in sickle cell disease. J Assoc Phy India. 1993;41(7):418-9.

17. Carlos TM, Harlan JM. Leukocyte-endothelial adhesion molecules. Blood. 1994;84(7):2068-101.

18. Knight-Madden J, Forrester T, Lewis N, Greenough A. Asthma in children with sickle cell disease and its association with acute chest syndrome. Thorax. 2005;60(3):206-10.

19. Cohen RT, Madadi A, Blinder MA, DeBaun MR, Strunk RC, Field JJ. Recurrent, severe wheezing is associated with morbidity and mortality in adults with sickle cell disease. Am J Hematol. 2011;86(9):756-61.

20. Galadanci NA, Liang WH, Galadanci AA, Aliyu $\mathrm{MH}$, Jibir BW, Karaye IM, et al. Wheezing is common in children with sickle cell disease when compared with controls. J Pediatric Hematology/Oncology. 2015;37(1):16-9.

21. Lang JE, Hossain J, Blake K, Mercado A, Lima JJ. Pediatric Allergy, Immunology, Pulmonol. 2013;26(1):11-7.

22. Silva GE, Teixeira AC, Vergna JG, Salgado-Filho $\mathrm{N}$, Crivellentti LZ, Costa RS, et al. A novel case report of sickle cell disease-associated immunoglobulin A nephropathy: the diagnostic value of erythrocyte dysmorphism evaluation. International J Clin Exp Med. 2014;7(6):1619-22. 
23. FDA. Will you have Eczema with Sickle cell anaemia? eHealthMe, 2017. Available at: https://www.ehealthme.com/cs/sickle-cellanaemia/eczema/. Accessed on 08 Dec 2017.

24. Huang SW, Kao KJ. Use of thrombospondin level to predict the clinical course of atopic dermatitis associated with food hypersensitivity or skin infection. J Dermatol Sci. 1996;11(1):59-635.
Cite this article as: Ashwi S, AlobaisyA, Herzallah N, Alwaheed F, Hadi I, Alabbas D, et al. Atopic dermatitis in sickle cell children. Int J Community Med Public Health 2018;5:842-5. 